\title{
ANALISIS KEMAMPUAN DAYA SAING PT. DIRGANTARA INDONESIA GUNA MENDUKUNG SISTEM PERTAHANAN NEGARA
}

\author{
Adang Setia \\ Pusat Studi Sumber Daya Ekonomi Pertahanan Universitas Pertahanan \\ email: bung.adang@gmail.com
}

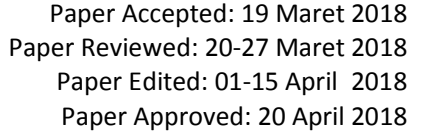

\begin{abstract}
The purpose of this master journal is to identify competitiveness PT. Dirgantara Indonesia (PTDI) to support the national defense system. This research is using the theory of reference are: (1) Five Forces Porter theory; (2) Design School Mintzberg theory; (3) Core Competence theory and Resource base strategy. PTDI is currently to the process of organizational transformation, the finding also suggest competitiveness can be said to be low. But there are a potential factors PTDI that lead to a competitive advantage in the industry. The researcher suggests that provide improve on the future development of the company PTDI and contribute to the realization of the national defense system.
\end{abstract}

Keywords: Core Competency Theory, Design School Mintzberg Theory, Industrial Competitiveness, Porter's Five Forces Theory, PTDI, Qualitative Research, and Resource-Based Strategy

\section{PENDAHULUAN}

Perusahaan PTDI merupakan perusahaan industri penerbangan yang pertama serta satusatunya di Indonesia dan Asia Tenggara. Perusahaan ini dimiliki oleh pemerintah Indonesia yang didirikan sejak tanggal 26 April 1976 dengan nama PT. Industri pesawat terbang Nurtanio yang kemudian berganti nama Industri Pesawat Terbang Nusantara (IPTN), serta akhirnya berganti nama menjadi PT. Dirgantara Indonesia sampai sekarang.

Perusahaan PTDI tidak hanya memproduksi pesawat tetapi juga helikopter, senjata, serta menyediakan pelatihan dan jasa pemeliharaan (maintenace service) untuk mesin-mesin pesawat. Perusahaan PTDI juga menjadi sub-kontraktor untuk industri-industri pesawat terbang di dunia seperti Boeing, Airbus, General dynamic, Fokker dan lain sebagainya.

Keberadaan industri strategis pertahanan PTDI merupakan perwujudan keinginan bangsa Indonesia menggunakan alutsista produksi dalam negeri yang ditujukan untuk mendukung sistem pertahanan yang memiliki sustainable self sufficiency power yang pasti (Kementerian Pertahanan RI, 2010). Peningkatan kemampuan PTDI dalam memproduksi sarana pertahanan yang modern dan berdaya saing akan meningkatkan kemandirian dalam pemenuhan kebutuhan sarana pertahanan nasional.

Kemampuan PTDI dalam pemenuhan alutsista udara nasional mendukung perwujudan sistem pertahanan negara. Sejumlah pesawat yang diproduksi oleh PTDI dapat digunakan oleh TNI untuk mendukung pertahanan nasional. Kemampuan PTDI dalam menyediakan pesawat angkut sedang untuk keperluan TNI diharapkan dapat menjaga keberlangsungan pengadaan alutsista udara untuk pertahanan nasional.

Sejumlah analisis mengenai kemampuan daya saing PTDI terus dilakukan untuk melihat kekuatan industri kedirgantaraan nasional. Berdasarkan hasil penelitian yang dilakukan oleh Isye Susanah Nurhasanah (2012) ditemukan sejumlah faktor endogen yang menjadi pembentuk kekuatan daya saing PTDI. Pada penelitian yang sudah dilakukan tersebut ditemukan sejumlah faktor seperti kemampuan adaftif yang baik dan absortif yang handal, yang menujukkan bahwa PTDI sesungguhnya berpotensi memiliki keunggulan kompetitif di pasar global. 
Pasang surut industri PTDI sangat terkait dengan pengalam krisis moneter Indonesia. Harus diakui bahwa pengalaman krisis moneter (1998) yang membuat perekonomian indonesia hancur dan memaksa Indonesia untuk meminjam dana pada IMF. Konsekuensi dari pinjaman dana tersebut memaksa Indonesia untuk menandatangi Letter of intent. Dampak buruk dari kesepakatan tersebut adalah dibatasinya modal pemerintah untuk membiayai industri pertahanan termasuk PTDI. Kondisi ini menyulitkan PTDI untuk melakukan pengembangan usaha dan bersaing dalam mengikuti dinamika industri.

Kondisi sumber daya manusia PTDI saat ini juga menjadi hal penting yang menjadi faktor pendukung daya saing industrinya. Banyaknya karyawan PTDI yang akan memasuki pensiun, memerlukan pergantian karyawan baru yang sesuai dengan tuntutan daya saing industrinya. Keterlambatan perekrutan karyawan yang seharusnya dilakukan tahun 2005 akibat kurangnya modal kerja, memperlambat penyegaran karyawan di PTDI. Oleh karena itu, kondisi sumber daya manusia menjadi faktor yang juga menentukan dalam mendukung daya saing industri PTDI.

Berdasarkan hal tersebut, maka akan dianalisis bagaimana kemampuan daya saing PTDI. Analisis tersebut akan didasarkan pada teori lima kekuatan daya saing (Five Forces Porter), dan teori kompetensi yang menjadi daya saing perusahaan. Mudah-mudahan analisis tersebut dapat menghasilkan strategi yang seharusnya dilakukan PTDI untuk meningkatkan daya saing perusahaannya.

\section{KERANGKA TEORI}

Dalam kerangka teori ini akan disampaikan sejumlah teori yang menjadi landasan teori analisis daya saing PTDI. Adapun teori yang akan dijelaskan dalam analisis ini diantaranya Teori Five Forces Porter, Teori "Design School" Mintzberg, teori kompetensi inti, dan teori kompetisi berbasis sumber daya. Selain itu akan dijelaskan bagaimana dukungan industri pertahanan terutama industri pesawat terbang PTDI terhadap perwujudan sistem pertahanan negara.

\section{a. Teori Five Forces Porter}

Teori lima kekuatan Porter (Five Forces) dikembangkan pertama kali oleh Michael Porter. Pemodelan dari teori ini digunakan untuk menganalisis bagaimana lingkungan yang kompetitif dari suatu perusahaan akan berpengaruh terhadap pemasaran suatu produk. Selain itu pemodelan dari teori ini juga digunakan untuk mengetahui keunggulan posisi kompetisi dari suatu perusahaan.

Penggunaan pemodelan lima kekuatan yang dimaksud Porter ini dilakukan dengan menguji beberapa variabel yang menjadi indikator penentu kekuatan bersaing suatu perusahaan. Adapun beberapa kekuatan penentu kemampuan bersaing perusahaan yang dimaksud Porter diantaranya:

1) Kekuatan penawaran pemasok

2) Kekuatan penawaran pembeli

3) Persaingan diantara perusahaan yang ada

4) Masuknya pesaing baru

5) Ancaman dari produk pengganti (substitusi)

Penggunaan Five Forces sebagai alat analisis diharapkan mampu menyajikan kerangka analitik yang mendalam guna membantu perusahaan menganalisis industrinya. Analisis yang dihasilkan ditujukan untuk meramalkan evolusi masa depan industri tersebut, memahami pesaing serta posisinya sendiri, serta menterjemahkan analisis ini ke dalam strategi bersaing dalam bisnis tertentu. Kerangka analisis Five Forces Porter dapat dilihat pada Gambar 1. 


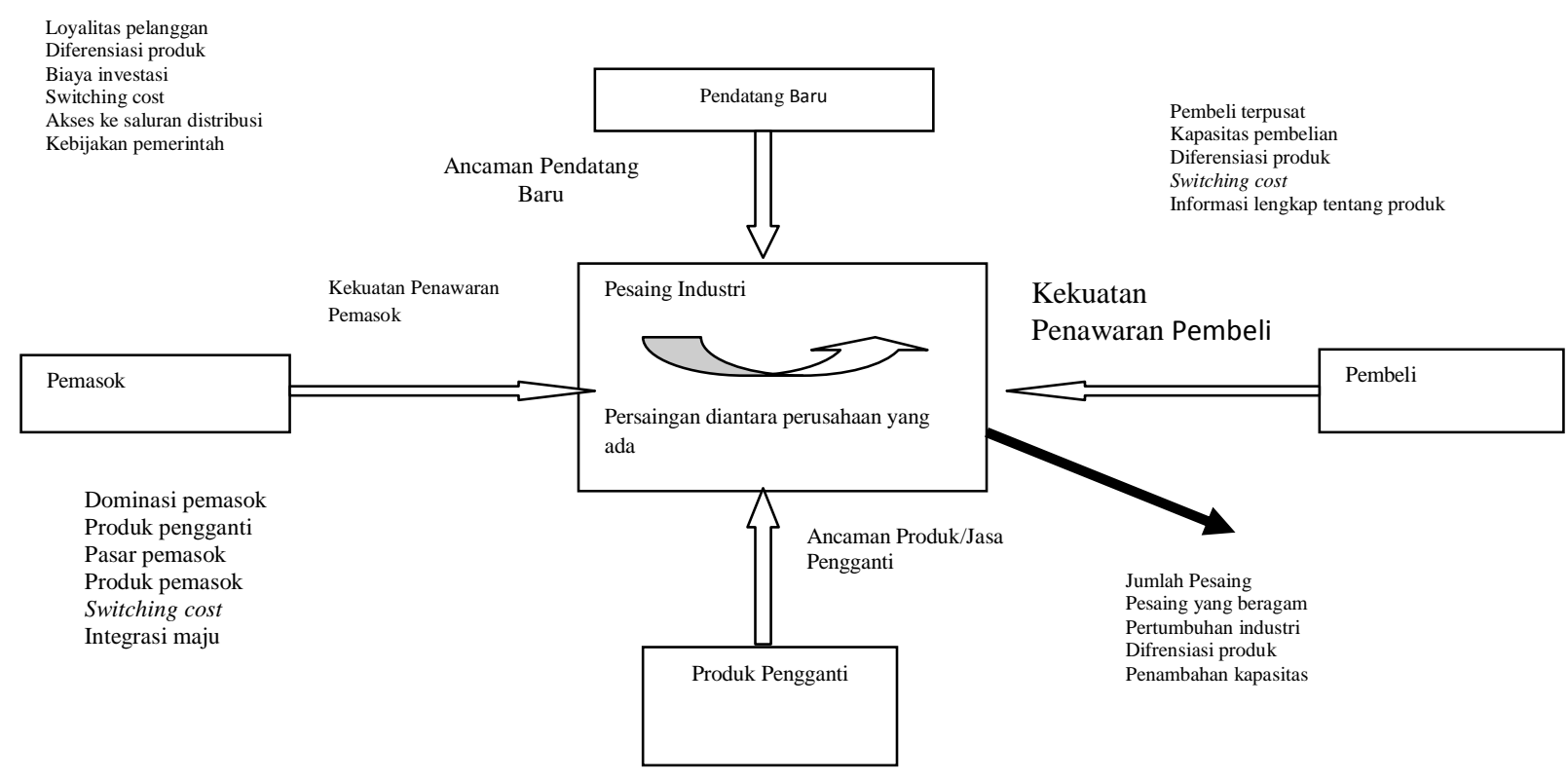

Gambar 1 Lima Kekuatan Bersaing pada Five Forces Porter

Sumber: Anthony E. Henry, 2011.

Penggunaan teori Five Forces Porter dalam penelitian ini untuk mengidentifikasi daya saing PTDI. Teori ini digunakan sebagai alat analisis daya saing PTDI yang menekankan pada kemampuan dalam menghadapi lingkungan organisasinya agar dapat kompetitif. Indikator dalam teori Five Forces Porter ini menjadi ukuran daya saing PTDI yang akan dianalisis.

\section{b. Teori-teori Keunggulan Berkompetisi (Competitive Theory)}

\section{1) Teori "Design School” Mintzberg (1990)}

Penggunaan teori design school Mintzberg ini untuk melengkapi analisis daya saing industri PTDI. Teori ini akan memperjelas bagaimana penerapan strategi PTDI dalam menghadapi peluang, kelemahan dan ancaman eksternal dengan menggunakan kekuatan internalnya. Berdasarkan hal tersebut maka akan digunakan analisis SWOT (strength, weakness, opportunity, dan threat), sehingga akan diperoleh kunci strategi yang diterapkan oleh PTDI. Penggunaan analisis SWOT ini untuk lebih memperjelas penerapan strategi yang dilakukan PTDI dalam menghadapi kompetisi dalam industri pesawat terbang.

\section{2) Teori Kompetensi Inti}

Penggunaan teori kompetensi ini digunakan untuk menganalisis daya saing industri PTDI dilihat dari kemampuannya dalam memberikan pelayanan produk terhadap konsumennya. Sejauh ini PTDI memiliki kompetensi dalam desain, rancang bangun dan produksi pesawat terbang yang mampu memenuhi kebutuhan sejumlah konsumen baik pemerintah dalam negeri maupun luar negeri. Teori ini akan memberikan analisis yang akan menjadi penegasan kekuatan daya saing PTDI dilihat dari kemampuannya dalam membangun industri pesawat terbang dan pelayanan produk yang dihasilkan terhadap konsumennya.

\section{3) Teori Strategi Berbasis Sumber daya (Resource-Based Strategy)}

Penggunaan teori berbasis sumber daya dilakukan untuk menganalisis kondisi sumber daya PTDI. Kemampuan sumber daya PTDI menjadi tolak ukur daya saing industrinya. Berbagai sumber daya PTDI mampu menjadi pendukung dalam menggerakkan industrinya agar dapat bersaing dalam industri pesawat terbang. Sebagai industri pesawat terbang yang bergerak dibidang desain, rancang bangun dan produksi PTDI memiliki sumber daya perusahaan yang dapat diidentifikasi sebagai variabel yang mendukung kemajuan industrinya. Oleh karena itu, strategi penggunaan sumber daya dapat menjadi ukuran yang mendukung kemampuan daya saing PTDI.

\section{METODE ANALISIS}

Metode analisis yang digunakan dilakukan dengan pendekatan studi kasus. Pendekatan studi kasus sendiri dapat didefinisikan sebagai kajian yang rinci dan intensif mengenai suatu latar, 
peristiwa, atau seorang individu tertentu (Bogdan, 1990; Ary, 1982).

Analisis ini akan menggunakan data primer dan data sekuder. Data primer yang digunakan merupakan hasil pengalian informasi dan data yang diperoleh dari PTDI. Sedangkan untuk data sekunder yang digunakan merupakan hasil penelitian yang dilakukan oleh peneliti atau institusi sebelumnya, yang akan menjadi data pendukung untuk dikonfirmasi kepada narasumber terkait, ketika wawancara dilakukan.

\section{HASIL ANALISIS DAN PEMBAHASAN}

\section{a) Analisis Berdasarkan Teori Five Forces Porter}

Penggunaan model five forces Porter sangat membantu mengidentifikasi kekuatan dan kelemahan daya saing PTDI dalam menghadapi suatu situasi bisnis. Oleh karena itu, model ini sangat membantu dalam pengambilan keputusan PTDI terutama untuk mengidentifikasi apakah suatu produk baru, layanan atau suatu bisnis dapat menghasilkan suatu keuntungan.

\section{1) Kekuatan PTDI Dalam Daya Tawar Terhadap Pemasok}

Untuk menunjang suplai komponen produksi pesawat terbang, PTDI menghadapi kondisi pemasok yang didominasi beberapa perusahaan. Sejauh ini bidang rekayasa, rancang dan bangun serta produksi pesawat terbang yang dilakukan disuplai oleh pemasok luar negeri. Dapat dikatakan PTDI memiliki ketergantungan yang cukup tinggi terhadap pemasok luar negeri. Pasokan komponen PTDI sampai saat ini masih dari luar negeri, namun keberlangsungan produksi pesawat masih dapat dilakukan. Selain itu, produksi pesawat PTDI setiap tahunnya rata-rata hanya 6 buah, cukup sulit untuk memiliki daya tawar terhadap pemasok.

Ketergantungan PTDI terhadap pemasok luar negeri mengindikasikan tidak adanya kemandirian industri pertahanan nasional. Daya saing industri PTDI dalam pesawat terbang nasional hanya dapat terwujud apabila memilki kemandirian dalam menciptakan industri-industri yang menjadi pemasok produksi PTDI dari dalam negeri. Sebagai sebuah industri strategis yang sebagian besar modalnya dari pemerintah, seharusnya PTDI juga mampu mendorong kemajuan industri lokal. PTDI bersama pemerintah harus mampu membuat stimulus menciptakan industri pendukung dalam negeri untuk menjadi pemasok dalam industri pesawat terbang nasional. Pemerintah saat ini memberikan perhatian lebih mengingat posisi PTDI sebagai 'lead integrator' dalam industri pertahanan di Indonesia.

Berdasarkan kondisi pemasok tersebut, dapat dikatakan PTDI belum memiliki kekuatan daya tawar pemasok yang mandiri yang dikontribusi oleh industri pemasok dalam negeri. Walaupun mampu menjaga keberlangsungan produksi dengan mengandalkan pemasok dari luar negeri, namun belum mampu menciptakan kemandirian industri pesawat nasional, sehingga dapat dikatakan memiliki daya saing industri yang masih rendah. Hal ini dikarenakan kemampuan daya saing dan kemandirian PTDI sebagai industri pertahanan yang modalnya dari pemerintah, seharusnya mampu menciptakan industri pendukung dalam negeri sebagai pemasok dari industrinya.

\section{2) Kekuatan PTDI Dalam Daya Tawar Terhadap Pembeli}

Indentifikasi daya tawar pembeli memberikan penjelasan bagaimana PTDI menerapkan strategi dalam menentukan harga serta memberikan penawaran peningkatan kualitas ataupun layanan lebih.

Untuk meningkatkan pembelian pesawat hasil produksi PTDI, dilakukan sejumlah strategi. Beberapa strategi yang dilakukan diperuntukkan agar PTDI juga memiliki kekuatan daya tawar terhadap pembelinya. Strategi yang diterapkan oleh PTDI untuk meningkatkan pembelian diantaranya membangung branding, masuk dalam pasar captive market, menawarkan produk yang customer oriented, dan mengambil konsumen utama pemeritah.

Produk yang dijual PTDI menyasar pasar yang 'captive market'. Pasar captive market ini merupakan pasar yang diidentifikasi oleh PTDI sebagai pasar khusus pesawat angkut dengan kualifikasi produk yang ditawarkan jumlah produsennya masih terbatas. Alasan mengambil ceruk pasar khusus ini, dikarenakan PTDI tidak berusaha menyaingi kompetitor yang besar seperti Airbus atau Boeing. Selain itu, produk yang 'captive market' tersebut membuat PTDI memiliki produk yang unggul di kelasnya yang secara perbandingan kualitas setara dengan Airbus dengan tidak membuat harganya paling murah dipasar.

Strategi PTDI terhadap pembeli lainnya adalah kemampuannya untuk memenuhi kebutuhan komponen pesawat sesuai pesanan pembeli. Kemampuan tersebut menjadikan PTDI mampu memberikan pelayanan baik terhadap konsumennya. Pelayanan produk yang berorientasi pada permintaan konsumen 
(customer oriented) ini juga didukung oleh kesiapan PTDI dalam menyiapkan dukungan perangkat komponen yang diperlukan oleh konsumen pada pesawat yang dipesannya. Sejauh ini PTDI mampu melayani kebutuhan penyesuaian komponen pesawat yang diproduksinya sesuai keinginan konsumen. Walaupun sejumlah komponen tersebut berasal dari jaringan supplier PTDI dari luar negeri, sebagai produsen pesawat PTDI mampu menjadi pelayan konsumen yang baik.

Untuk meningkatkan penjualan produksi pesawat, PTDI fokus untuk melayani pembelian pemerintah. Sejauh ini pembelian dari pemerintah merupakan andalah dari PTDI untuk menjual produk pesawatnya. Dilihat dari regulasi memang menuntut pemerintah untuk membeli produk PTDI selama sesuai dengan kebutuhan yang diperlukan. Regulasi tersebut menjadi posisi yang menambah daya tawar PTDI terhadap pembelinya terutama konsumen pemerintah.

Penjualan produk PTDI terus mengalami kenaikan setiap tahunnya. Trend kenaikan penjualan produk PTDI dapat dilihat sejak tahun 2007 hingga tahun 2014. Kenaikan perolehan kontrak PTDI terutama diperoleh dari pemerintah. Dengan adanya proses Restrukturisasi dan Revitalisasi (RR) yang dimulai pada tahun 2011 dan penambahan Penyertaan Modal Negara (PMN) tunai sebesar 1,4 triliun, mendorong kemampuan PTDI untuk memenuhi tanggungan kontrak produksi pesawat yang sempat tertunda dari pemerintah. Untuk melihat trend kenaikan penjualan dan perolehan kontrak PTDI dapat dilihat pada Gambar 2 dan Tabel 1 dibawah ini, diantaranya:

\section{Kinerja Perolehan Kontrak \& Penjualan 2007-2014 (dalam Triliun Rp)}

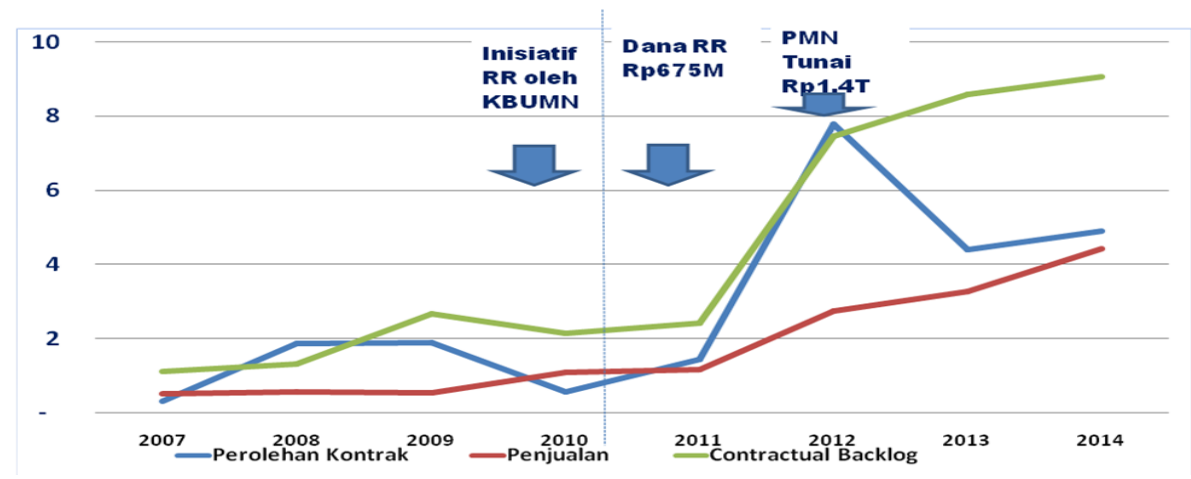

Gambar 2 Grafik Kinerja Perolehan Kontrak dan Penjualan PTDI

Sumber: PT. Dirgantara Indonesia, 2014

Tabel 1. Status Pesawat-Pesawat Yang Sudah Dikirim PTDI

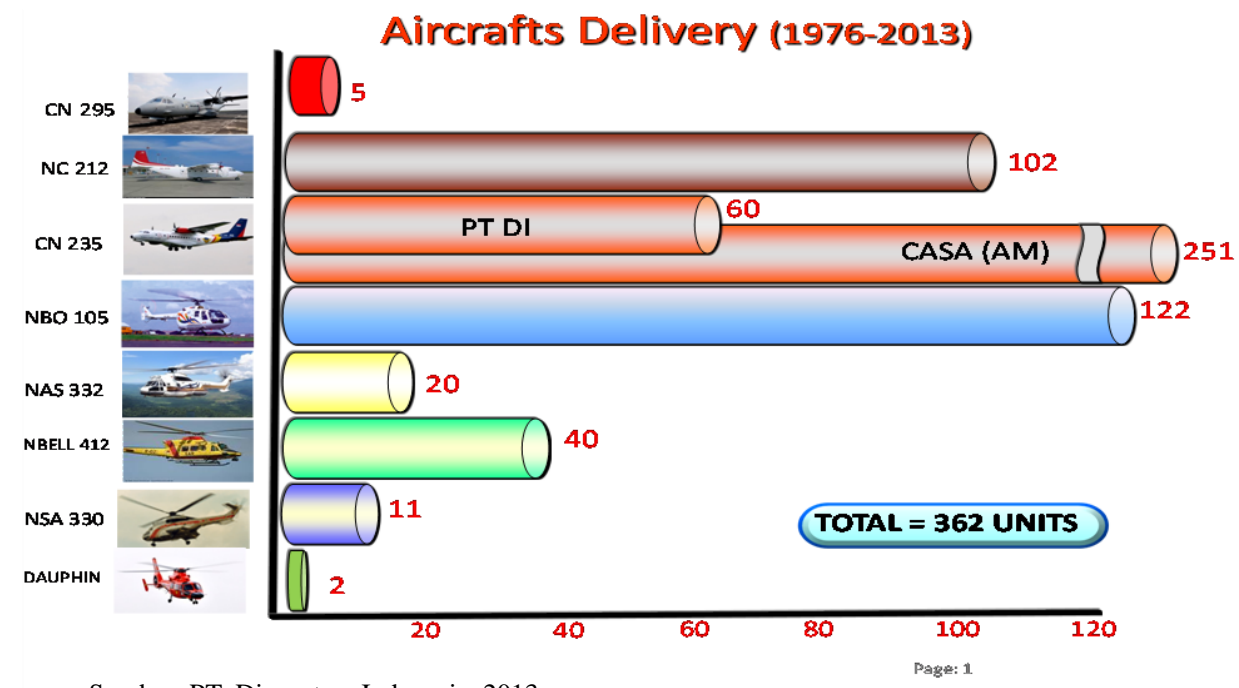

Sumber: PT. Dirgantara Indonesia, 2013 
Kekuatan daya tawar PTDI terhadap pemerintah sebagai pembeli bukan saja persoalan regulasi, tetapi kualitas produk yang ditawarkannya dianggap lebih baik. Pertimbangan untuk membeli pesawat dari PTDI oleh pemerintah sudah menjadi keharusan, selama memenuhi kualifikasi kebutuhan pesawat yang diperlukan.

Dengan demikian, PTDI mampu memberikan daya tawar terhadap pembelinya. Bebarapa strategi seperti membangun branding, mengambil ceruk pasar yang 'captive market', kemampuan dalam menawarkan produk yang customer oriented, dan fokus pada pemenuhan pemerintah, dapat dianggap sebagai kekuatan PTDI terhadap pembelinya.

\section{3) Kekuatan PTDI Dalam Menghadapi Intensitas Persaingan Bisnis \\ Untuk menghadapi intensitas persaingan} bisnis produk pesawat terbang, PTDI berusaha menggunakan beberapa strategi. Strategi yang dilakukan yaitu membangun branding, mengambil ceruk pasar yang 'captive market', berusaha membuat produk yang 'customer oriented ', dan fokus pada permintaan pemerintah.

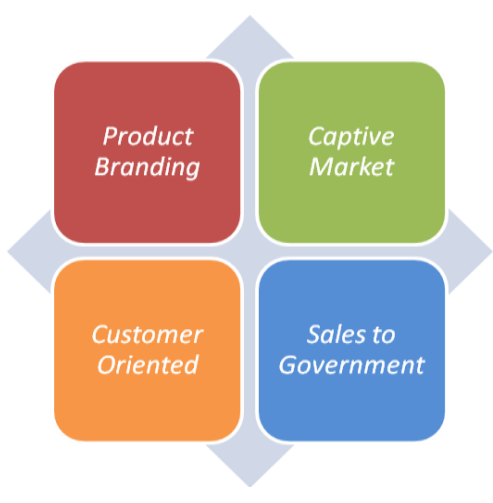

Gambar 3 Strategi Penjualan PTDI

Kemampuan PTDI menawarkan produk yang terdeferensiasi di pasar pesawat, menjadi kekuatan dalam menghadapi intensitas persaingan dipasarnya. Kekuatan dalam membuat produk yang unggul dikelasnya dan produk pesawat yang pengoperasiannya bisa disesuaikan dengan kebutuhan konsumen menjadi strategi yang digunakan. Beberapa pesaing dari PTDI dapat dikatakan hanya perusahaan yang mampu memproduksi pesawat yang memiliki kemiripan semata. Walaupun banyak pesaing industri pesawat di dunia seperti Boeing dan Airbus atau CESNA untuk perusahaan yang setara, namun PTDI mampu bersaing dalam produksi pesawat dikelasnya.

Penciptaan dan Penguatan daya saing terus dilaksanakan oleh PTDI. Ada bebarapa hal yang telah dilakukan oleh PTDI untuk menghadapi intensitas persaingan, diantaranya: (1) membuat kesepakatan dengan Airbus Military untuk bekerjasama dalam pemasaran dan penjualan dan membagi wilayah pasar, PTDI memimpin di pasar Asia Pasifik; (2) dengan masuknya CN-295, PTDI bisa menawarkan pesawat kelas medium selain juga CN-235 (kecil-medium) dan NC-212 (kecil) serta menjadi 4 jenis pada 2016 dengan masuknya N-219 (kecil); (3) pesawat CN-235 dan NC-212 dievolusi untuk memenuhi permintaan pasar dan kompetitif;
(4) PTDI menjamin produksi lebih cepat dan tepat waktu;

(5) mencari dukungan pemerintah untuk menghadapi pesaing lain yang juga didukung oleh negaranya; (6) PTDI masih mengusahakan mitra lain yang dapat membantu pemasaran dan leasing penjualan pesawat khususnya untuk N-219.

\section{4) Kekuatan PTDI Dalam Menghadapi Pesaing Baru}

Di dalam negeri tidak ada pesaing industri pesawat terbang bagi PTDI. Tidak ada industri pesawat swasta yang memiliki kemampuan untuk mendesain dan memproduksi. Jikalau ada perusahaan swasta yang masuk, besar kemungkinan akan menempatkan sebagai pemilik pesawat dan akan menjadikan PTDI sebagai kontraktor. Walaupun banyak orang atau kelompok pengusaha yang bisa mengumpulkan uang, namun mereka akan berpikir ulang untuk membuat industri pesawat seperti PTDI yang memiliki kemampuan desain dan produksi.

Oleh karena itu, sebagai industri pesawat terbang nasional PTDI belum menghadapi ancaman pendatang baru. Pendatang baru sebagai pesaing dalam industri pesawat terbang sulit untuk membangun karena persoalan modal, kemampuan 
teknologi, dan relasi. Kondisi ini yang membuat PTDI menjadi satu-satunya industri pesawat terbang yang ada di Indonesia bahkan Asia Tenggara yang memiliki kemampuan desain dan produksi.

\section{5) Kekuatan PTDI Dalam Menghadapi} Ancaman Barang Substitusi

Adanya produk atau jasa pengganti akan mengurangi jumlah laba potensial yang akan didapat dari suatu industri. PTDI tidak memiliki ancaman dalam menghadapi perusahaan yang mampu membuat barang substitusi. Hal ini dikarenakan industri pesawat terbang memiliki aturan tertentu yang bersifat internasional. Jikalau ada pesaing dimungkinkan dari perusahaan prinsipal yang memproduksi barang yang sejenis dengan PTDI.

Industri pesawat terbang mengikuti aturan industri pesawat secara internasional. Setiap pesawat yang diproduksi sesuai dengan kualifikasi desain dan produksi yang sudah ditentukan. Sejumlah komponen yang dibuat untuk pesawat semua sudah ditetapkan dengan kebutuhan desain dan produksi pesawat. Hal ini yang membuat setiap industri pesawat terbang tidak mampu memproduksi pesawat maupun komponen yang mensubstitusi produk industri lainnya secara sembarangan. Tidak ada produk substitusi yang sama dari produk yang diproduksi pada industri pesawat terbang, karena industri pesawat terbang sangat ketat dalam memberikan sertifikasi untuk pesawat maupun komponen yang dibuat.

Oleh karena itu, Tidak adanya produk komponen pengganti pada setiap pesawat terbang yang diproduksi, menjadikan industri yang membuat pesawat terbang memiliki daya saing dalam menghadapi produk substitusi. Jikalau ada produk pesaing dimungkinkan dari perusahaan prinsipal PTDI seperti produk dari Airbus military. b) Keunggulan Bekompetisi PTDI

\section{1) Strategi Berbasis Sumber Daya PTDI}

Pengembangan strategi berbasis sumber daya, perkembangan industri PTDI dalam industri pesawat nasional dapat dikatakan sangat potensial. Potensi yang sangat tampak adalah kemampuan sumber daya manusianya. Harus diakui bahwa hanya sedikit negara di dunia yang mampu mengembangkan industri pesawat terbang dalam bidang desain, rancang bangun dan produksi pesawat. Kemampuan sumber daya manusia menjadi sorotan, mengingat banyak sekali orang Indonesia yang kemudian diperkerjakan di luar Negeri dalam produksi pesawat dikarenakan PTDI sempat tidak dapat memberdayakan mereka akibat mengalami krisis ekonomi pada tahun 1998.

Kurangnya permodalan menjadikan PTDI mengalami kesulitan dalam menjalankan perusahaan. Hal ini yang kemudian mendorong DPR RI dan pemerintah melakukan restrukturisasi dan revitalisasi ( $R R$ ) pada PTDI. Upaya yang dilakukan untuk mendorong $\mathrm{RR}$ tersebut memberikan dampak terhadap keberlangsungan industri PTDI.

Industri PTDI mendapatkan Penyertaan Modal Negara (PMN) non tunai pada tahun 2011, dan PMN tunai pada 2012 dalam selang setahun. Usaha PTDI untuk mendapatkan PMN sudah dirintis sejak 2005. Hal ini bisa disebut projek terobosan dan quick win, karena PTDI tidak mungkin membayar hutang dan mengganti Penyertaan Modal Sementara (PMS) yang totalnya senilai Rp1,571 triliun. Kemudian dengan PMN non tunai ini PTDI segera mengubah wajah buruk akunting dan neraca perusahaan menjadi lebih cantik sehingga dapat diterima oleh perbankan untuk mendapatkan modal kerja. Bukti terobosan ini adalah dukungan perbankan berupa non cash loan ke PTDI untuk mengerjakan kontrak-kontrak baru dan regular pada tabel 2, diantaranya:

Tabel 2 Tabel Pemberian Non Cash Loan dari Perbankan Untuk PTDI

\begin{tabular}{|l|l|l|}
\hline \multicolumn{1}{|c|}{ Bank } & \multicolumn{1}{|c|}{ Tahun } & \multicolumn{1}{c|}{ Non Cash Loan } \\
\hline BRI & 2012 & USD 88 juta dan EUR 97 juta \\
\hline & 2013 & USD 40 juta dan EUR 163 juta \\
\hline BNI & 2012 & USD 130 juta \\
\hline EXIM & 2012 & USD 4,2 juta \\
\hline & 2013 & USD 10 juta \\
\hline
\end{tabular}

Sumber: PT. Dirgantara Indonesia, 2014

Sementara itu dari sisi sumber daya manusia PTDI mengalami penyesuaian yang terus menerus. Terjadinya krisis pada tahun 1998 telah banyak merumahkan karyawan 
yang ada, sehingga sebagian bahkan ada yang bekerja di luar negeri. Sedangkan kondisi karyawan hari ini sebagian besar sedang memasuki masa pensiun.

Masih besarnya karyawan yang memasuki pensiun di PTDI dikarenakan keterlambatan dalam merekrut karyawan. Jumlah karyawan yang akan memasuki pensiun dari tahun 2011 sampai 2015 mencapai 1403 orang (47\%) dari keseluruhan karyawan tetap. Kondisi ini yang menjadikan PTDI sementara mengalami penggelembungan karyawan akibat karyawan pensiun masih dipekerjakan. Alasan masih dipekerjakan karyawan yang sudah memasuki pensiun ini diperuntukkan memberikan pendampingan kepada karyawan muda.

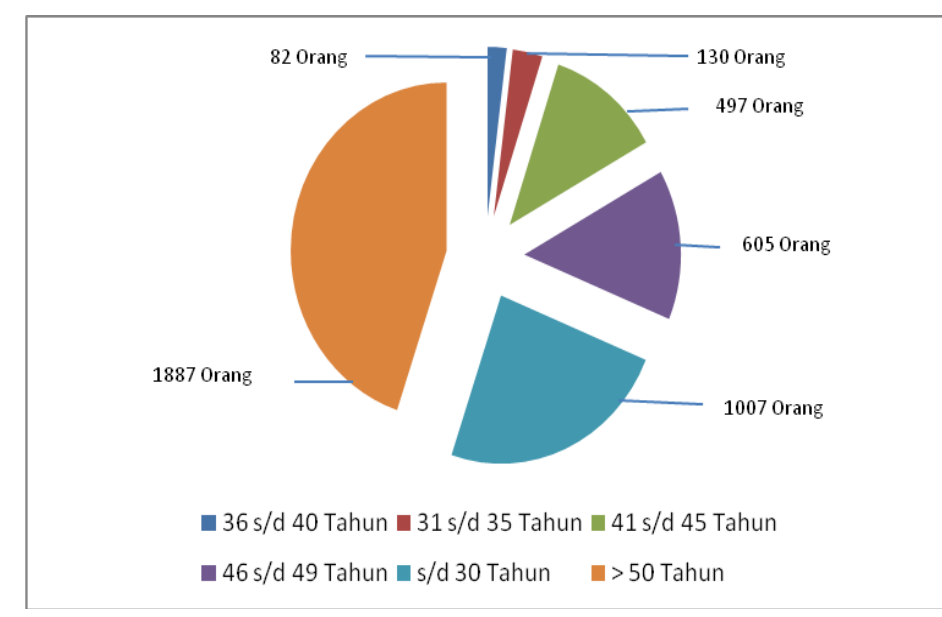

Gambar 4 SDM PTDI Berdasarkan Usia

Sumber: PT. Dirgantara Indonesia, 2014

Berdasarkan pertimbangan kondisi keuangan dan sumber daya manusia yang masih dalam pemulihan maka dapat dikatakan PTDI memiliki tantangan daya yang masih rendah. Kemampuan dalam mengakumulasi modal yang dapat memberikan profit perusahaan yang tinggi menjadi hal yang diharapkan dari PTDI. Sumber daya manusia yang mampu mendukung keberlangsungan usaha juga menjadi hal yang harus diselesaikan oleh PTDI. Oleh karena itu, proses RR yang dilakukan diharapkan mampu menuntaskan persoalan penyehatan keuangan perusahaan dan menjaga keberlangsungan usaha PTDI.

\section{2) Penerapan Strategi PTDI}

Menurut teori "Design School" Mintzberg (1990) dalam menciptakan keunggulan bersaing perusahaan harus mendesain strategy yang cocok antara peluang dan ancaman eksternal dengan kemampuan internal yang dimiliki. Keputusan strategi yang diambil disesuikan dengan pedoman pilihan alternative dari grand strategy, kemudian didukung dengan menumbuhkan kapabilitas inti yang dimiliki yang merupakan kompetensi khusus (distinctive competency) dari pengelolaan sumber daya perusahaan.
Kompetensi khusus itu diciptakan melalui strategy generic milik Porter, seperti strategi biaya rendah, differensiasi, dan fokus, serta didukung oleh nilai-nilai budaya perusahaan yang relevan.

Dengan mengambil titik awal tahun 2011, strategi besar PTDI diantaranya: (1) mengeluarkan perusahaan dari kemelut keuangan (neraca, arus kas, dan modal kerja) dan (2) segera bertranformasi (program RR) sambil tetap menjaga pekerjaan-pekerjaan terkontrak serta mendapatkan kontrak baru.

Untuk memperjelas penerapan strategi PTDI berikut analisis SWOT (Strength, Weakness, Opportunity, Threat) secara sederhana. Analisis SWOT dilakukan untuk melihat potensi kekuatan, kelemahan, peluang dan hambatan yang dimiliki PTDI, sehingga mampu mencapai daya saing industri pesawat yang optimal. Berikut analisis SWOT terkait PTDI, diantaranya:

a) Strength

Kekuatan atau kelebihan yang dimiliki oleh PTDI dalam industri pesawat terbang dapat dijelaskan sebagai berikut, diantaranya:

(1) Memiliki kemampuan dalam bidang desain, rancang bangun dan produksi dalam bidang 
pesawat untuk tingkat nasional dan Asia Tenggara.

(2) Memiliki Reputasi bisnis dalam bidang industri pesawat terbang yang baik karena sudah berdiri cukup lama sejak tahun 1976.

(3) Memiliki kemampuan yang unggul dalam produksi pesawat angkut (komuter) yang sudah diakui oleh banyak negara.

\section{b) Weakness}

Kelemahan secara internal yang dimiliki oleh PTDI dalam industri pesawat terbang dapat dijelaskan sebagai berikut, diantaranya:

1) Defisit cash flow dan ekuitas negatif.

2) Tidak mampu memenuhi komitmen on time delivery kepada customers.

3) Penjualan pesawat terbang dibawah kapasitas terpasang (rata-rata 6 unit/tahun).

4) Ketidak seimbangan utilisasi fasilitas produksi.

5) Demografi SDM yang tidak proporsional.

\section{c) Opportuniy}

Peluang bisnis industri PTDI dalam pesawat terbang dapat dijelaskan sebagai berikut, diantaranya:

(1) Komitmen Pemerintah untuk melakukan revitalisasi industri pertahanan dan mengutamakan penggunaan produk dalam negeri dengan dibentuknya KKIP dan ditetapkannya UU No 16 Tahun 2012 tentang Industri Pertahanan Dalam Negeri.

(2) Potensi pasar pesawat terbang, perawatan pesawat terbang dalam negeri dan Asia Pasifik yang besar.

(3) Trend outsourcing komponen pesawat yang besar dari industri pesawat terbang utama (seperti Airbus dan Boeing).

(4) Potensi penguatan pasar dan operasional melalui penguatan aliansi/kolaborasi strategis dan industrial cooperation serta menjadi bagian dari global supply-chain industri dirgantara.

\section{d) Threat}

Ancaman atau tantangan PTDI dalam industri pesawat terbang dapat dijelaskan sebagai berikut, diantaranya:

(1) Terbukanya pasar dalam negeri terhadap persaingan terhadap produk asing.

(2) Tuntutan regulasi dan kualifikasi dari Original Equipment Manufacturers untuk Aircraft Servives.

(3) Rendahnya anggaran Pertahanan Indonesia untuk membeli produk-produk PTDI dalam jumlah yang cukup untuk memenuhi kapasitas terpasang.

(4) Potensi tuntutan hukum dari mantan karyawan PTDI dan masalah hukum yang belum tuntas memperburuk kinerja operasional dan keuangan, namun juga menghambat potensi tumbuh dan keberlangsungan hidup PTDI.

(5) Kewajiban kepada berbagai customer yang tertunda.

Berdasarkan analisis SWOT sederhana tersebut maka ada penyesuaian strategi perusahaan yang dilakukan oleh PTDI. Strategi perusahaan dirancang untuk mampu mempertahankan Misi PTDI dan secara bertahap mencapai Visi PTDI. beberapa kunci strategi yang diterapkan PTDI dapat diuraikan sebagai berikut, diantaranya:

(1) Mendukung pemenuhan kebutuhan alutsista nasional.

(2) Mengembangkan produk dan pemasaran $\mathrm{CN}-235$.

(3) Melaksanakan kerjasama industri dengan perusahaan pesawat terbang terkemuka.

(4) Meningkatkan daya saing produk (delivery tepat waktu dan biaya).

(5) Peningkatan kehandalan sistem informasi (ERP).

(6) Restrukturisasi usaha dan regenerasi SDM.

(7) Kerjasama pengembangan pesawat N-219 yang dibiayai lembaga/institusi pemerintah dan PTDI sebagai subkontraktor.

(8) Secara keuangan berusaha mengoptimalisasi dana PMN dan penerimaan dari hasil penjualan pesawat.

Dengan demikian PTDI mampu menyiapkan industrinya untuk berkompetisi dengan sejumlah strategi yang telah disesuaikan. Pelaksanaan RR yang dilakukan sejak tahun 2011 sudah mulai 
menunjukkan kemajuan perusahaan PTDI untuk kembali menjalankan industrinya.

\section{3) Kompetensi Inti PTDI}

Teori kompetensi Inti sering dikemukakan oleh para ahli misalnya, Gary Hamel dan CK. Prahalad dalam karyanya "Competiting for The Future" (1994).

Untuk melihat kemampuan daya saing dan keunggulan berkompetisi maka diperlukan penjelasan kemampuan kompetensi inti PTDI. kompetensi inti menjadi ukuran bagaimana PTDI mampu memberikan pelayanan yang baik dalam bidang produksi pesawat terhadap konsumennya. Sebagai sebuah industri pesawat terbang yang memiliki kemampuan desain, rancang bangun dan produksi satusatunya di Indonesia dan Asia tenggara, PTDI terus berusaha memberikan pelayanan produk yang maksimal. Kemampuannya dalam melayani permintaan konsumen menunjukkan PT DI memiliki kompetensi inti dalam penyediaan pesawat terbang terutama untuk pesawat angkut.

Berikut ini uraian bagaimana kemampuan PTDI dalam memberikan pelayanan terhadap konsumennya, diantaranya:

a) PTDI telah menyerahkan 2 unit $\mathrm{CN}$ 295 ke Kemhan pada tahun 2012 dan akan menyerahkan 3-4 unit pada tahun 2013, serta 3-4 unit lagi pada tahun 2014 dari kontrak total 9 unit CN-295 untuk menggantikan pesawat Fokker-50 TNI AU.

a) PTDI telah menyerahkan 15 unit Bell-412 ke Kemhan untuk TNI AL (3 unit) dan TNI AD (12 unit) selama tahun 2011 - 2013, dan akan menyerahkan 4 unit lagi tahun ini untuk TNI AD (3 unit) dan Polisi (1 unit) dari kebutuhan total sekitar 32 unit Bell-412.

b) PTDI sedang menyelesaikan 2 unit NC-212 dan 2 unit NAS-332 Super Puma pesanan Kemhan untuk TNI AU dan akan diserahkan pada tahun 2014.

c) PTDI sedang menyiapkan 6 unit EC725 Cougar pesanan Kemhan untuk TNI AU dan akan diserahkan pada tahun 2014.

d) PTDI sedang menyelesaikan 3 unit CN-235 Coast Guard pesanan Kemhan untuk TNI AL dan akan diserahkan pada tahun 2013 dan 2014.

e) PTDI sedang menyiapkan 2 unit Dauphin (Eurocopter) untuk BASARNAS dan akan diserahkan pada tahun 2013. f) PTDI sedang menyelesaikan 1 unit NC-212 untuk Ministry of Agriculture (MOAC) Thailand dan akan diserahkan pada awal 2014.

g) PTDI terus memproduksi di atas 400 shipsets pertahun berbagai komponen struktur untuk Airbus jenis A320/321, A330, A340, dan A350 serta 36 shipsets pertahun komponen struktur untuk Airbus jenis A380 (Jumbo Jet)

h) PTDI memproduksi 10 shipsets main fuselage dan tailboom helikopter EC725/EC-225 Eurocopter untuk tahun 2012 dan 15 shipset untuk tahun 2013.

Kompetensi PTDI melayani konsumen dalam pesawat terbang sudah cukup baik. Namun, untuk memiliki daya saing dan kemandirian dalam industri pesawat terbang nasional, diharapkan juga mampu mendorong industri pendukungnya untuk maju. Hal ini berkaitan dengan Tingkat Kandungan Dalam Negeri (TKDN) yang ada dalam setiap produk dari PTDI.

Oleh karena itu, dapat dikatakan PTDI memiliki kompetensi inti dalam produksi pesawat terbang dan sejauh ini mampu melayani kebutuhan konsumen secara optimal. Walaupun demikian, dari segi kemampuan daya saing belum dikatakan baik, karena sejumlah komponen masih mengandalkan dari luar negeri dan belum bisa menstimulasi industri pendukung dari dalam negeri.

\section{4) Dukungan Industri PTDI Terhadap Perwujudan Sistem Pertahanan Negara} Sejauh ini keberadaaan PTDI sebagai industri pesawat nasional yang mendukung kebutuhan TNI masih tetap diharapkan mampu membangun industri pertahanan yang mandiri dan berkelanjutan. Hal ini dikarenakan PTDI merupakan satu-satunya industri pesawat nasional yang sangat diandalkan dalam memenuhi kebutuhan alutsista udara untuk pertahanan negara.

Sebagai industri pesawat terbang yang diandalkan PTDI belum bisa membuat pesawat tempur. Sejumlah pesawat yang mampu didukung oleh PTDI untuk keperluan pertahanan lebih banyak jenis pesawat angkut. Berikut kontrak pengadaan pesawat yang dipesan oleh pemerintah yang dimenangkan oleh PTDI, untuk keperluan pertahanan negara, diantaranya: 
Tabel. 4.2 KONTRAK YANG DIPEROLEH OLEH PTDI PADA PERIODE 2009 - 2013

\begin{tabular}{|c|c|c|c|c|c|}
\hline & 2009 & 2010 & 2011 & 2012 & 2013 \\
\hline 1 & $\begin{array}{l}3 \text { Unit CN235 } \\
\text { Patmar TNI AL }\end{array}$ & $\begin{array}{c}3 \text { Unit NAS332 } \\
\text { Super Puma TNI } \\
\text { AU }\end{array}$ & $\begin{array}{c}6 \text { Unit Bell412EP } \\
\text { TNI AD }\end{array}$ & $\begin{array}{c}9 \text { Unit CN295 } \\
\text { Miltrans TNI AU }\end{array}$ & $\begin{array}{c}\text { I Unit NC212 } \\
\text { Miltrans TNI AU }\end{array}$ \\
\hline 2 & $\begin{array}{c}\text { I Unit NBO105 TNI } \\
\text { AD }\end{array}$ & & $\begin{array}{c}\text { I Unit NC212-400 } \\
\text { MOAC }\end{array}$ & $\begin{array}{l}13 \text { Unit Bell412EP } \\
\text { TNI AD \& TNI AL }\end{array}$ & $\begin{array}{c}16 \text { Unit Bell412EP } \\
\text { TNI AD }\end{array}$ \\
\hline 3 & $\begin{array}{c}\text { I Unit NC212-200 } \\
\text { Transwisata }\end{array}$ & & & $\begin{array}{c}\text { I Unit EC725 } \\
\text { Cougar TNI AU }\end{array}$ & $\begin{array}{c}2 \text { Unit Bell412EP } \\
\text { POLRI }\end{array}$ \\
\hline 4 & & & & $\begin{array}{c}2 \text { Unit Bell412EP } \\
\text { BASARNAS }\end{array}$ & $\begin{array}{c}2 \text { Unit EC725 } \\
\text { Cougar TNI AU }\end{array}$ \\
\hline 5 & & & & & $\begin{array}{c}6 \text { Unit EC155 } \\
\text { Panther TNI AL }\end{array}$ \\
\hline 6 & & & & & $\begin{array}{l}2 \text { Unit Dauphin } \\
\text { BASARNAS }\end{array}$ \\
\hline
\end{tabular}

Sumber: PT. Dirgantara

Walaupun hingga saat ini kondisi 'supplai chain' komponen pendukung industri PTDI 100 persen bahan baku yang digunakan dari impor, namun kedepan akan coba didorong adanya industri pendukungnya. Adanya industri pendukung tier 1, 2, 3 dan 4 yang dilakukan oleh industri dalam negeri, diharapkan mampu memperbesar kemandirian dan peran industri kedirgantaraan nasional bagi perekonomian serta mampu mendukung perwujudan sistem pertahanan negara.

Dengan demikian dukungan PTDI terhadap perwujudan sistem pertahanan negara terutama untuk penyediaan alat angkut sedang dikatakan cukup baik. Keberlangsungan ketersedian pesawat yang diperlukan untuk keperluan pertahanan sementara mampu disedikan oleh PTDI. Namun untuk mendukung keberlangsungan alustista udara perlu dibangun kemandirian industri pesawat terbang dengan dibangunnya industri pendukung dalam negeri, mengingat sejumlah komponen pesawat PTDI masih mengandalkan industri pendukung dari luar negeri.

\section{KESIMPULAN}

Berdasarkan hasil analisis yang sudah dilakukan, maka dapat diberikan kesimpulan, diantaranya:

a. Kemampuan daya saing Industri pesawat terbang PTDI dapat diidentifikasikan sebagai berikut, diantaranya:

1) Daya tawar PTDI terhadap pemasoknya sangat rendah sehingga belum memiliki daya saing industri yang baik. Sebagian besar komponen produksi pesawat PTDI mengadalkan pemasok dari luar negeri.

2) Daya tawar PTDI terhadap pembelinya cukup baik, sehingga dapat dikatakan memiliki potensi daya saing dari sisi produk pesawat yang dihasilkannya.

3) Kekuatan PTDI dalam menghadapi intensitas persaingan dapat dikatakan cukup baik. Hal ini dikarenakan PTDI mampu mengambil ceruk pasar yang produknya unggul dikelasnya.

4) Kekuatan PTDI dalam menghadapi barang substitusi dari produk yang dihasilkan tidak terlalu besar. Jikalau ada produk substitusi hanya dimungkinkan dari produk yang dihasilkan oleh perusahaan prinsipalnya.

5) Kekuatan PTDI dalam menghadapi ancaman pesaing baru cukup baik. Hal ini dikarenakan dipastikan tidak ada pesaing baru yang mampu bersaing dalam industri pesawat terbang di tingkat nasional yang memiliki kemampuan desain, rancang bangun dan produksi seperti PTDI.

b. Keunggulan dalam berkompetisi PTDI dapat diidentifikasikan sebagai berikut, diantaranya:

1) PTDI memiliki potensi berkompetisi dari sisi sumber daya. Sumber daya PTDI yang paling terlihat adalah sumber daya manusia dan sumber daya dana. Sumber daya manusia 
PTDI teruji kemampuannya, namun memerlukan pengelolaan dan pembinaan lebih lanjut mengingat jumlah karyawan yang pensiun cukup banyak. Sumber dana PTDI cenderung membaik setelah adanya konversi hutang yang dimilikinya menjadi PMN dan mendapat tambahan dana untuk revitalisasi dan restrukturisasi, sehingga secara perusahaan sekarang menjadi lebih "bankable".

2) PTDI memiliki potensi berkompetisi untuk mengelola strategi perusahannya sehingga mampu bersaing dalam industri pesawat terbang. Proses tranformasi organisasi mampu membangkitkan reputasi PTDI sebagai perusahaan yang dapat mengembangkan industri pesawat terbang.

3) PTDI memiliki potensi berkompetisi dari kompetensi inti yang dimiliki terutama dalam melayani konsumen dalam produk pesawat angkut. Keberhasilan PTDI berproduksi dan mengembangkan pesawat angkut mampu meberikan pelayanan terhadap konsumen baik pemerintah maupun luar negeri.

c. PTDI sementara mampu memberikan dukungan terhadap perwujudan sistem pertahanan negara. Sebagai industri pesawat terbang PTDI mampu menghasilkan sejumlah pesawat yang dapat digunakan oleh TNI terutama untuk jenis pesawat angkut. Namun, dari sisi kemandirian industri belum dikatakan baik mengingat sejumlah komponen produksi masih mengandalkan industri pendukung dari luar negeri. Oleh karena itu, PTDI diharapkan mampu menstimulasi industri pendukung dalam negeri, untuk menjamin kemandirian dan keberlangsungan pengadaan alutsista udara nasional.

\section{DAFTAR PUSTAKA}

Aligica, P Drago and Weinstein, Kenneth R (Edited). (2009). The Essential Herman Kahn In Defense of Thinking. New York: Lexington Book

Balam, David N dan Michael Veseth. (1996). Introduction to International Political Economy. New Jersey: Prentice Hall.

Gilpin, Robert. (2001). Global Political Economy Understanding The International Economic Order. Pricenton University Press: New Jersey.
Hartley, K. \& Sandler, T . (Eds). (1995). Hanbook of Defense Economics (Vol 1). Amsterdam: Elsevier.

Hedin, Han., Hirvensalo, Irmeli., Vaarna, Markko. (2011). The Handbook of Market Intelligence: Understanding, Compete and Grow in Global Markets. John Wiley \& Sons, Ltd: United Kingdom.

Henry, Anthony E. (2011). Understanding Strategic Management, second edition. Oxford University Press: New York.

Hill, C. (2010). International Business: Competing in the Global Marketplace, Third Edition, McGraw-Hill, New York.

Jonker, jan., J.W. Pennink, Bartjan., Wahyuni, Sari. (2011). Metodologi Penelitian: Panduan untuk Master dan Ph.D. di Bidang Manajemen. Jakarta: Salemba Empat.

Rahakundini, Connie. (2008). Postur TNI Ideal. Jakarta: Gramedia.

Suryana. (2003). Kewirausahaan: Pedoman Praktis, Kiat dan Proses Menuju Bisnis. Edisi Revisi. Jakarta: Salemba Empat.

Collis, David J and Rukstad, Michael G. (2008). Can You Say What Your Strategy Is. Harvard Business Review.

Drew, Stephen A., Kelley, Patricia C., Kendrick, Terry. (2006). Class: Five Element of Corporate Governance to Manage Strategic Risk. Kelley School of Business, Indiana University.

Hambrick, Donald C and Fredrickson, James W. (2005). Are You Sure You Have A Strategy. Academy of Management Executive (Vol. 19. No.4): Columbia.

Holmberg, Stevan R and Cummings, Jeffrey L.(2009). Building Succesful Strategic Alliances: Strategic Process and Analytical Tool for Selecting Partner Industries and Firms. Long Range Planning 42 (2009) 164 - 193. York: Elsevier.

Porter, Michael E. (2008). The Five Competitive Forces That Shape Strategy. Harvard Business Review.

Trimanto S. Wardoyo dan Lena (2010). Peranan Auditor Internal Dalam Menunjang Pelaksanaan Good Corporate Governance - Studi Kasus Pada PT. Dirgantara Indonesia. Akurat Jurnal Ilmiah Akuntansi No.3 Tahun ke-1 SeptemberDesember 2010. Bandung: Universitas Kristen Maranatha.

Kementerian Pertahanan Republik Indonesia. Buku Minimum Essential Force Komponen Utama Tahun 2010.

Kementerian Pertahanan Negara Republik Indonesia .Buku Postur Pertahanan Negara.

Undang-undang Nomor 3 Tahun 2012 Tentang Pertahanan Negara.

Undang-undang Republik Indonesia No. 16. Tahun 2012 tentang Industri Pertahanan. 
Tim PTDI (2013). Corporate Transformation Program PT. Dirgantara Indonesia.

Andriani, Retta. (2012). Pengembangan PT. Pindad Melalui Faktor-faktor Pembentuk Keunggulan Kompetitif. Database Thesis Perpustakaan Universitas Pertahanan Indonesia.

Nurhasanah, Isye S. (2012). Analisis Keunggulan Kompetitif PT Dirgantara Indonesia Berbasis Pendekatan Hybrid Antara Model Five Forces Porter dan Dynamic Capability. Database Thesis Perpustakaan Universitas Pertahanan Indonesia.

Putra, Andretti RA. (2010). Analysis Of Resources And Capabilities Organizations As Internal Sources Of Competitive Advantage PT. Metrodata E-Bisnis Dell Division. Database Thesis Gadjah Mada University.

Suhendi, Asep. (2009). Keunggulan Kompetitif Melalui Strategi Penguasaan Wilayah, Kompetensi Sumber Daya Manusis Dan Orietasi Pasar - Studi Kasus Pada PT. Indosat
Tbk. Database Thesis Perpustakaan Universitas Diponogoro.

"Contoh Proposal Penelitian Kualitatif." http://civicchannel.wordpress.com/2012/03/30/c ontoh-proposal-penelitian-2/. Diakses Tanggal 31 Oktober 2012 Pukul 16:55 WIB.

“Tinjauan Umum PT. Dirgantara Indonesia (Persero).

http://elib.unikom.ac.id/files/disk1/613/jbptunik ompp-gdl-afizaltanj-30625-9--unikom_-a.pdf. Diakses Tanggal 20 Oktober 2013, Pukul 20:48 WIB.

"Sulitnya PT. Dirgantara Indonesia untuk Berkembang di Indonesia." http://suarakpk.com/sulitnya-pt-dirgantaraindonesia-untuk-berkembang-indonesia/. Diakses 20 Oktober 2013 Pukul 20:36 WIB.

“ The Comparative Advantage Theory of Competition." http://sdh.ba.ttu.edu/ra\%20theory-jm95.pdf. Diakses Tanggal 20 Oktober 2013, Pukul 20:34 WIB. 